\title{
From LABOR PROCESS THEORY TO CRITICAL MANAgEMENT STUdieS
}

\author{
John Hassard ${ }^{\mathrm{i}}$, University of Manchester \\ John Hogan, University of London \\ Michael Rowlinson, University of North London
}

\begin{abstract}
Critical management studies scholars occupy a tenuous position in business schools. Their location and intellectual trajectory needs to be understood in the political context of the historical defeat of the Left since its highpoint in 1968. One of the tributaries of critical management studies is labor process theory, which derives from Braverman's (1974) classic critique of the degradation of labor in capitalist work organization. Whereas Braverman attempted to restore confidence in the potential of the working class to fulfill its Marxist destiny to lead a revolutionary transformation of society, any such confidence in the second coming of communism has long since evaporated from critical management studies. Instead of adhering to Marx's or Braverman's historical visions critical management studies scholars have increasingly turned to Foucault or critical theorists such as Adorno or Marcuse, who provide the basis for a deconstruction of Marxian eschatology. This is presented as an intellectual progression in critical management studies, but we argue that it is a manifestation of the defeat of the Left and the need to temper our radicalism in the context of neo-liberal hegemony.
\end{abstract}

\section{INTRODUCTION}

The invitation to introduce an American readership to the more radical strains of European critical management studies strikes us as paradoxical. The suggestion that what passes for "radical" among American management academics generally pales in comparison to what Europeans are writing is puzzling, because for us, as English-speaking British academics, many of our most important reference points are American. To start with, although British industrial sociologists and organization theorists may have dominated discussions of labor process theory for the last twenty years or so (e.g., Knights \& Willmott, 1990), it still derives from the debates generated by Harry Braverman's Labor and Monopoly Capital (1974). Braverman's 
humanistic critique of capitalist work organization remains a classic. It is even acknowledged as such in Deal and Kennedy's (2000, p. 137) recent revisit of corporate cultures. If we turn to critical theory, we should not forget that the leading German members of the Frankfurt School, Theodor Adorno, Erich Fromm, Max Horkheimer, and Herbert Marcuse, found refuge from the Nazis in the USA. After the Second World War, Fromm and Marcuse stayed in the USA, where they developed their influential critiques of capitalism (e.g., Fromm, 1997; Marcuse, 1964). What is more, many of the best contemporary commentators on critical social theorists, such as Marx, Foucault, and Habermas, are now American (e.g., Best, 1995). And when we see the intellectual defeat of rationality in organization theory (Weick, 1979) being turned into eight winning business traits by best-selling American management gurus (Peters \& Waterman, 1982), it is the observation of an American Marxist cultural theorist, Frederic Jameson, that postmodernism is the new cultural logic of capitalism (1984), which makes us smile (Clark, 2000, p. 298).

Our impression is that while radical thought has found a refuge in American academia, academics in American business schools are cut off from their radical colleagues in other faculties. As a result American organization studies encounters radicalism through the roundabout route of European organization studies, much of which draws on radical streams in American thought.

In this paper, we want to address the precarious and contradictory position of academics in business schools who see themselves as being in some sense leftist, radical or critical. We are particularly concerned with those academics in the field of organization studies who can be included as part of the loose community that describes itself as "critical management studies". We recognize that any notion of what it means to be "critical" is necessarily contested, and we intend to address some of the problems associated with it. We certainly do not intend to make any exclusive claims for the term, although we readily acknowledge that for some constituencies in critical management studies it carries connotations of identification with critical theory derived from the Frankfurt School (e.g., Alvesson \& Willmott, 1996). Our intention is to reflect on the relationship between critical management studies and the defeat of the Left. In order to do so we trace the trajectory of a major contributory stream in critical management studies, namely labor process theory. After setting out the extent of the defeat of leftist ideas in late twentieth century Britain and the United States, we provide a series of commentaries on the development of critiques of capitalism since the 1960s that are relevant for understanding the location of contemporary critical management studies. 


\section{THE DEFEAT OF THE LEFT}

It would be difficult to exaggerate the defeat suffered by the Left in the last decades of the twentieth century. We could rehearse the familiar litany of disasters for leftists in the fields of electoral politics or industrial relations to make our point. Instead, we prefer to quote a fictionalized account from Terry Eagleton, Britain's foremost Marxist literary theorist, of what the situation might be if there had been a significant defeat:

Imagine a radical movement which had suffered an emphatic defeat. So emphatic, in fact, that it seemed unlikely to resurface for the length of a lifetime, if even then. The defeat I have in mind is not just the kind of rebuff with which the political left is depressingly familiar, but a repulse so definitive that it seemed to discredit the very paradigms with which such politics had traditionally worked. It would be less a matter of hotly contesting these notions than of contemplating them with something of the mild antiquarian interest with which one might regard Ptolemaic cosmology or the scholasticism of Duns Scotus. They, and the language of conventional society, would now seem less ferociously at odds than simply incommensurable - the discourses of different planets rather than of adjacent nations. What if the left were suddenly to find itself less overwhelmed or out-manoeuvred than simply washed up, speaking a discourse so quaintly out of tune with the modern era that, as with the language of Gnosticism or courtly love, nobody even bothered any longer to enquire into its truth value? What if the vanguard were to become the remnant, its arguments still dimly intelligible but spinning off rapidly into some metaphysical outer space where they became nothing but a muffled cry? (Eagleton, 1996, p. 1)

Eagleton's account captures the sense that the Left was not defeated in some heroic last stand, but that most of us at some time have had the feeling of waking up one day to realize the apparent irrelevance of everything we once believed in.

One of Britain's leading Marxist commentators, Perry Anderson, has summed up the situation facing the Left at the start of the twenty-first century:

The Soviet bloc has disappeared. Socialism has ceased to be a widespread ideal. Marxism is no longer dominant in the culture of the Left. Even Labourism has largely dissolved. To say that these changes are enormous would be an under-statement...the principal aspect of the past decade...can be defined as the virtually uncontested consolidation, and universal diffusion, of neo-liberalism...

Ideologically, the novelty of the present situation stands out in historical view. It can be put like this. For the first time since the Reformation, there are no longer any significant oppositions-that is, systematic rival outlooks-within the thought-world of the West; and scarcely any on a 
world scale either, if we discount religious doctrines as largely inoperable archaisms... Whatever limitations persist to its practice, neoliberalism as a set of principles rules undivided across the globe: the most successful ideology in world history...

With rare exceptions-France in the winter of 1995-labour has been quiescent for over twenty years now. Its condition is not a mere outcome of economic changes or ideological shifts. Harsh class struggles were necessary to subdue it in Britain as in the United States. If somewhat less cowed in Europe, workers still remain everywhere on the defensive. The only starting-point for a realistic Left today is a lucid registration of historical defeat. (Anderson, 2000, pp. 9-10)

The Left no longer constitutes a threat to what J.K. Galbraith (1993) has termed the "culture of contentment", in which it is accepted that certain features of the capitalist corporation, such as discrimination, deskilling, and downsizing, while regrettable, are unavoidable concomitants of capitalist competition, and the efficiency that the capitalist corporation enjoys. Reformminded management theorists may continue to argue that the long-term success of organizations depends upon their concern for employees (e.g. Pfeffer, 1998). But with the defeat of the Left, it has become less credible to argue that unless corporate management confronts issues such as racial and gender inequality and increasing income inequality the very existence of capitalist corporations may be threatened. As Lester Thurow puts it, "Capitalism has a current advantage in that with the death of communism and socialism, it has no plausible social system as an active competitor. It is difficult to have a revolution against capitalism without an alternative ideology" (1996, p. 407). The Financial Times can dismiss the entertaining spectacle of May Day anti-capitalist protests as "a reaction of the left to a world in which old ideological battles have been rendered obsolete by the rejection of Marxism in favour of free market orthodoxy" (1 May 2001).

The advance of neo-liberalism has also undermined confidence in the public sector, which is routinely denounced as "bureaucratic", as if capitalist corporations are not bureaucracies (Galbraith, 1993). As Habermas highlights in his recent collection of essays (2001), the advance of corporate power and the erosion of the public sphere has eroded democratic accountability in society.

These are not the circumstances in which we would expect to find a thriving critical management studies community in the heartland of academic knowledge capitalism, the business school. For us the "critical" credentials of this community must be open to question when for the most part it barely acknowledges the extent and significance of the defeat of the Left. We see this as an indication that critical management studies is detached from the intellectual heritage of the Left and from contemporary radical social 
movements. In order to understand how we ended up being part of critical management studies we want to go back to a highpoint for the Left.

\section{THE ROMANCE OF '68 AND DISAFFECTION WITH THE WORKING CLASS}

We cannot help but confuse history and memory in our account of the context in which Braverman's Labor and Monopoly Capital appeared because our own political awakening took place in the 1970s. Even in the seventies Leftists looked back on 1968 as a highpoint. In retrospect, '68 has come to symbolize the brief return of the specter of communism to haunt not just Western capitalism but state socialism as well. However, by the time of the twentieth and thirtieth anniversaries of ' 68 the fond nostalgia for "the fire last time" (Harman, 1998) merely provided the occasion for romantic reminiscences of revolutionary posturing (e.g., Ali \& Watkins, 1998). By 1998, which was also the 150th anniversary of The Communist Manifesto, the specter of communism was no more threatening than the "frightful hobgoblin" that he was when he first appeared in the English language (Wheen, 1999, p. 124).

Romanticism aside, it should be remembered that in the late 1960s the Left in general, and the American Left in particular, was by no means enamoured with the working class. There was increasing disillusionment with the role of organized labor in relation to race, gender, and the anti-war protests. A widely held view on the Left was that the only hope of change came from intellectuals and students, and that it was only nostalgia that led revolutionaries to expect action from the working class. The loss of faith in the revolutionary potential of the working class found theoretical justification in the writings of critical theorists, such as Marcuse's One Dimensional Man (1964), as well as in the work of leading American Marxist economists, Baran and Sweezy, in Monopoly Capital (1968).

As the title of his work suggests, Braverman was heavily influenced by Baran and Sweezy. What Baran and Sweezy attempted to do was to reconcile Marxism with the growing importance of large corporations in the capitalist economy. In doing so they dispensed with some basic tenets of Marxist orthodoxy (Desai, 1979, pp. 114-115), in particular the "the law of the tendency of the rate of profit to fall" (LTRPF), which predicts that economic crises are inevitable within capitalist economies (see Shaikh, 1991). Fundamentalist Marxists, espousing revolutionary politics, have consistently claimed that abandoning the LTRPF inevitably leads to reformist politics.

The consequence of abandoning the LTRPF is that crises are no longer seen as inevitable. Baran and Sweezy's view was that the Great Depression of the 1930s, "accorded admirably with Marxian theory", but by the 1960s, the 
problem for Marxist political economy was to come to terms with the seemingly permanent "affluent society" (1968, p. 17). Their purpose was to explain the "Golden Age" of capitalism (Marglin \& Schor, 1990), the period following the Second World War when there was "no recurrence of severe depression" (Baran \& Sweezy, 1968, p. 17). They did not anticipate the inevitable relapse of capitalism into its normal state of crisis, but attempted to explain how an abnormal state of stability could be sustained indefinitely. As the threat of global economic dislocation loomed larger in the 1970s and 80s, fundamentalist Marxists could take Baran and Sweezy to task for failing to anticipate the onset of further capitalist crises (Harman, 1984; Mandel, 1981, p. 34).

Baran and Sweezy (1968) also diverged from orthodox Marxist political economy in their characterization of the modern capitalist corporation. They accepted the managerialist argument that there has been a significant separation of ownership from control, which has freed corporate management from control by the owners of capital. However, they did not go so far as to accept that the separation of ownership from control undermines Marxist class theory (Nichols, 1970; Zeitlin, 1989, p. 9). Baran and Sweezy's work can be seen as a continuation from Berle and Means' (1932) managerialist thesis, and their position can be characterized as "Marxist managerialism" (Scott, 1997, p. 28), insofar as they "accept that a managerial revolution has taken place, so that control of the giant corporation rests in the hands of management", although they "do not see the emergence of a managerial class as changing the basic objective of the firm, which remains the reaping of profits" (Sawyer, 1979, pp. 135-136; Pitelis, 1987, p. 15).

Baran and Sweezy's analysis of monopoly capitalism can be regarded as a Marxian version of the liberal critique of the power of large corporations that was popularized by Galbraith (1967). This critique directs attention away from corporations' control over process of production (Semmler, 1982). According to Marxist Fundamentalists, the managerialist argument that there has been a separation of ownership and control undermines the theoretical justification for revolutionary politics because it suggests that corporate management enjoys sufficient discretion to be able to accommodate labor (Nichols, 1970; Zeitlin, 1989).

As a result of their managerialism, Baran and Sweezy condemned capitalism not for its inevitable economic crises but for the measures that have to be taken to stave off crises. Thus they could be said to have anticipated the more recent anti-corporate movement (Klein, 2001). The absorption of an ever-increasing surplus involves the proliferation of unproductive activities. Baran and Sweezy's (1968, p. 116) particular target was the waste of resources involved in the sales efforts of major corporations. Thus they could be said to have anticipated the more recent anti-corporate movement. Baran and 
Sweezy's argument was that with the expansion of activities such as the sales efforts of large corporations and military expenditure, "a large and growing part of the product of monopoly capitalist society is, judged by genuine human needs, useless, wasteful, or positively destructive" (p. 331). The irrationality of capitalism is not the waste of human potential that results from inevitable crises, but the way in which the surplus has to be used for irrational rather than egalitarian purposes in order to prevent economic crises (Desai, 1979, p. 114). Baran and Sweezy's conclusion was that 'an economic system in which such costs are socially necessary has long ceased to be a socially necessary system' (1968, p. 144).

Although still convinced of the need to overthrow capitalism, Baran and Sweezy abandoned the orthodox Marxist belief in the revolutionary potential of industrial workers in advanced capitalist countries. Their neglect of the labor process $(1968$, p. 22; Friedman, 1977, p. 29) can be interpreted as an outcome of their view that the organized core of workers in the basic industries was a diminishing minority of the working class that had largely been integrated ideologically as corporate employees and as consumers through a share in the surplus. Instead, they looked to "the impoverished masses in the under-developed countries" for a revolutionary impetus (1968, p. 22).

Managerialism has been consistently criticized by leading Marxist sociologists such as Maurice Zeitlin (1989), who defends a vision of the working class leading the revolutionary overthrow of capitalism. Zeitlin has disputed the view that there has been a separation of ownership and control, and dismissed the political implication of managerialism that the working class is finished as a force to be reckoned with. One of the most prominent postwar European Marxist economists, Ernest Mandel, has set out the objections of Marxist Fundamentalists to the political implications of Baran and Sweezy's economic analysis. According to Mandel, Baran and Sweezy stress the capacity of the corporate capitalist system "to integrate the working class socially and thereby ensure its perpetuity—albeit under conditions of permanent quasi-stagnation-rather than its inevitable collapse". Therefore they

have to project the system's real enemies outside the system itself: third world peasants; marginalized super-exploited layers; and so on. But they are nowhere able to demonstrate that these social forces anywhere have a potential social and economic strength comparable to that of the modern proletariat. Since such forces are not vital to the system's basic productive relations, they can be variously ignored or integrated, or crushed, without making the system incapable of functioning. (Mandel, Baran \& Sweezy,1981, p. 86) 


\section{THE RESTORATION OF A REVOLUTIONARY ROLE FOR WORKERS AND THE DESKILLING THESIS}

While works such as Baran and Sweezy's Monopoly Capital and Braverman's Labor and Monopoly Capital were obviously years in the making, they each appear to have caught the mood of elements on the Left at the time of publication. In the late 1960s and early 1970s, American social critics rediscovered workers' grievances, and Braverman offered an overarching explanation for rising working class militancy. For example, he cited the strike in January 1972 at the brand new General Motors plant in Lordstown, Ohio, as evidence of workers' resistance to the dehumanizing conditions even in one of the "most advanced" plants in the auto industry (1974, p. 33). Braverman's position was contradictory in that he clearly followed Baran and Sweezy's managerialist economic analysis (Friedman, 1990, p. 15), but he rejected their third-worldist politics (Foster, 1989, p. 240). Instead, he attempted to restore confidence in the revolutionary role of workers in advanced capitalist countries.

According to Braverman's deskilling thesis, under monopoly capitalism work is degraded because of an inexorable tendency for the conception of work to be separated from its execution. Conception is concentrated in an ever-smaller section of the workforce, while most workers are reduced to executing tasks conceived by others. Work therefore becomes increasingly meaningless for the majority of workers. This process is epitomized by the destruction of craft skills in the United States during the twentieth century through the application of Taylor's scientific management. There are certainly better historical studies than Braverman's of the rise of Taylorism and scientific management in the United States between 1860 and 1920 (e.g., Clawson, 1980; Nelson, 1980). But few can compare with the force of Braverman's "historical vision", which is in our view implicitly "informed by an imaginative vision of an alternative future" (Best, 1995, p. xv). We feel that it is Braverman's historical vision that explains the enduring appeal of his work beyond the confines of academia, even if his vision strikes radical organization theorists as being "rather romantic" (Perrow, 1986, p. 51).

Braverman's acceptance of Baran and Sweezy's managerialism, and his implicit acceptance of their abandonment of the LTRPF, means that it is difficult to reconcile labor process theory, derived from Braverman, with orthodox Marxist political economy (Friedman, 1990, p. 15), although this has not deterred Marxist fundamentalists from trying to do so (Callinicos, 1989, p. 69; Cohen, 1987, pp. 35, 48; Spencer, 2000). However, labor process theory, following Braverman, has been largely detached from Marxist critiques of political economy. Thus, for example, with a few notable exceptions (e.g., Friedman, 1984; Neimark \& Tinker, 1987; Rowlinson, 
1997), labor process theorists have ignored or dismissed (e.g., Littler, 1990, pp. 72-76) neo-liberal organizational economics derived from Coase (1990), which does at least take work organization within capitalist firms seriously (Williamson, 1980), unlike mainstream neoclassical economics.

As a consequence of his managerialism Braverman himself could be said to have opened the way for those labor process theorists (e.g., Knights, 1990; Willmott, 1990) who began to invoke Foucault in the 1980s to argue that power rather than exploitation drives domination in the labor process (Nichols, 1992, p. 11; Pritchard, 2000, p. 178). Marxist fundamentalists see the link between the rate of profit and class struggle as vital since it relates the labor process to capitalist development. They claim that otherwise class is merely an instance of the more pervasive human struggle for domination, as in Weberian or Nietzsche-inspired theories (Callinicos, 1989, pp. 69-70). Against the Nietzsche-Weber tradition, fundamentalist Marxists assert that "one of Marx's central claims is...that exploitation explains domination", and that domination within production is only a necessary condition in the historically specific capitalist mode of production (Callinicos, 1989, pp. 71, 163).

According to Braverman Taylorism represents "nothing less than the explicit verbalization of the capitalist mode of production" (1974, p. 86). Thus, Braverman concluded that the separation of conception from execution is "the ideal toward which management tends, and in pursuit of which it uses and shapes every productive innovation" in order that the labor process "is henceforth carried on by management as the sole subjective element" (Braverman, 1974, pp. 171-172). The implication is that the constraint upon management in the labor process is the self-imposed requirement to preserve a role for itself-not the external constraint to extract a sufficient level of surplus value to satisfy the owners of capital. The subjective ideology of management becomes the dynamic of the capitalist labor process.

At the risk of exaggerating Braverman's managerialism, it is worth noting that while Baran and Sweezy could be said to follow Berle and Means, there is a strong resemblance between Braverman's position and Burnham, the archmanagerialist who coined the expression "the managerial revolution". According to Burnham, writing in the 1940s, with the advent of modern mass production "the gap, estimated both in amount of skill and training and in difference of type of function, between the average worker and those who are in charge, on the technical side, of the process of production is far greater today than in the past" (1962, p. 79). 


\section{LABOR PROCESS THEORY AND MANAGEMENT STRATEGY}

The defeat of the Left was not consolidated until the 1990s when Clinton and Blair demonstrated that that there really were no alternatives to the neoliberal consensus (Anderson, 2000, p. 11). But looking back we can say that the downturn in class struggle set in during the mid-1970s, in the sense that from then onwards workers were on the defensive in most industrial disputes (Cliff, 1979). From then on too the events of the late sixties and early seventies increasingly appeared in retrospect to represent lost opportunities for the Left. Braverman's portrayal of Taylorism as the one and only implacable strategy that could be pursued by capitalist management, short of an apocalyptic challenge to managerial authority, began to lose its appeal for Leftists once the prospect of any such challenge to management receded. The prospect of being able to identify an underlying dynamic of the capitalist labor process in an effort to unify working class resistance in the workplace became a forlorn lost hope. Most labor process theorists settled for devising "complex typologies" of "labor control strategies," and an elaborate "sociological classification of industries and periodizations of change" (Littler \& Salaman, 1982, pp. 264, 265). The clever-sounding justification for this taxonomitis was that "capitalist reality is more complex" than Braverman imagined it to be (Littler \& Salaman, 1982, p. 258). Our contention is that the presentation of internalized political defeat as intellectual progress is a defining feature of critical management studies, and here we can see an early manifestation of it in labor process theory.

The discovery of diverse strategies for managing labor robbed labor process theory of Braverman's argument that workers are subject to an inevitable process of "deskilling and homogenization" (Elbaum, et al., 1979). Braverman, like Marx before him, could be accused of taking the pronouncements of capitalist ideologues such as Andrew Ure, Charles Babbage, and Frederick Taylor at face value (Lazonick, 1979). Labor process theory could be said to have returned to a managerialist position, by granting corporate management sufficient autonomy to be able to pursue its own interests independently of the requirements of the owners of capital and to control and accommodate labor by means other than scientific management combined with human relations.

With the defeats inflicted on workers' organizations mounting from the mid-1970s onwards, it became more difficult for Labor Process Theorists to continue championing workers' resistance to management strategies as the harbinger of revolution. Instead, labor process theorists were increasingly tempted to make direct appeals to management to adopt strategies deemed to be more acceptable for workers and less likely to provoke resistance. Or at least, those labor process theorists in Britain who could present themselves as 
holding such a position could find employment in the expanding business schools as opportunities for academics dried up in the discipline of sociology. In British business schools at the time, a few sophisticated management theorists were drawing on labor process theory to persuade managers to choose control strategies that would avoid provoking unnecessary resistance from workers, so that managers would then refute the deskilling thesis by their own actions (e.g., Child, 1984). There is little to distinguish this type of management theory from reformist labor process theory, except for the terminology used. Here again we suggest that our narrative captures the role of chance, what historians refer to as contingency, rather than intellectual progression in the migration of British labor process theorists from industrial sociology to organization studies.

The view that a variety of managerial strategies are compatible with capitalist production, some more acceptable to workers than others, opens the way to reformism insofar as it denies the ultimate necessity for a revolutionary transformation of society. The major concern becomes deciding which strategies of resistance workers should adopt in order to persuade management to pursue more palatable strategies. According to the reformist versions of labor process theory that gained momentum in the 1980s, management strategy can be changed by means other than resistance. If, say, "soft" management strategies are deemed to be intrinsically better for workers by labor process theorists (e.g., Alvesson \& Willmott, 1992), then workers' resistance can be subordinated to changing management strategy by other means. This line of argument has ended up with apparently respected advocates of critical management studies offering strictures on the unacceptability of the outdated practice of output restriction by labor "in a system of "post-industrial relations"' (Jacques, 1999, p. 211). The ascendancy of reformism in labor process theory reflects the general feeling of many former revolutionaries that the best hope for changing capitalist corporations is by appealing to the long-term self-interest of managers, rather than by advocating resolutely anti-management resistance by workers. Again, a response to defeat can be construed as a triumph whenever Labor Process Theorists win a hearing from business or government.

\section{Revolutionary Optimism and Reformist Pessimism}

Although Braverman followed Baran and Sweezy's managerialism, his politics were definitely revolutionary. The terminology is admittedly confusing because while Braverman's economic analysis can be termed "managerialist", his political stance was decidedly in the anti-management tradition of revolutionary Marxism. What Braverman tried to do, to suit his own political purpose, was to resurrect a law-like tendency, akin to the law of 
the tendency of the rate of profit to fall (LTRPF), within the corporation. He derived the inexorable separation of conception from execution from the almost unconscious collective subjectivity of management. This is why Taylorism is so problematic within Braverman's analysis since the more managers deny it the more they are alleged to believe in Taylorism (1974, p. 87). Braverman's functionalism (Littler \& Salaman, 1982, p. 256) could thus easily give way to conspiracy theory (Callinicos, 1989, p. 79).

Braverman has been continually, if not willfully, misrepresented as "depicting a progressively de-skilled and decidedly non-revolutionary working class" (Tanner, et al., 1992, p. 444). Labor process theorists have criticized Braverman for failing to acknowledge workers' continual capacity to resist and substantively change management strategy in order to improve their situation. These theorists see themselves as being more optimistic than Braverman. They have presented the "overall trajectory of the labor process debate' since Braverman as "a trend toward increasing optimism" (Tanner, et al., 1992, p. 444). It almost seems that the pessimism of labor process theorists with regard to the prospects for revolution has prevented them from even perceiving Braverman's revolutionary optimism. The paradox is that, whereas these critics celebrate the capacity of workers to effect piecemeal reform of the capitalist labor process, they have almost all lost faith in the potential of the working class to lead a revolutionary transformation of society.

If Braverman is linked too closely with Baran and Sweezy's politics, then his position can be interpreted as a pessimistic, "neo-Marcusian view of virtually contradiction-free capitalist hegemony in monopoly capitalism", where the "emphasis on the profound dominance of capital is qualified only in terms of the persistence of inarticulate working class disgruntlement which might, under the pressure of extreme crisis, reopen the prospects for revolutionary politics" (Elger, 1982, pp. 361-362).

In the only published response to critics before his death, Braverman was forthright in rejecting the "pessimistic" interpretation of Labor and Monopoly Capital as a description of the unending "degradation of labor". He asserted that: "Neither Marx nor Engels considered themselves 'pessimists' on that account; on the contrary, they found in this unremitting assault of capital upon labor the precondition for revolt" (Braverman, 1976, p. 124). The difference between Braverman and those fundamentalist Marxists who share his "confidence in the revolutionary potential of the working classes of the socalled developed capitalist countries" is that for the fundamentalists the LTRPF and its concomitant economic crises provide the imperative for revolution (Braverman, 1976, p. 124). In contrast, Braverman believed that it was the increasing and inevitable degradation of work that would compel the working class to fulfil "the task which they alone can perform" (Braverman, 
1976, p. 124). There is a parallel between the rhetoric of the LTRPF and Braverman's deskilling thesis. Braverman had a revolutionary vision but his Marxist-managerialist mentors, Baran and Sweezy, robbed him of the crisis, in its classic Marxist formulation, as the "precondition for revolt". In place of the LTRPF, Braverman substituted a contradiction of capitalism between the ability to buy off the working class in the sphere of circulation with greater consumption of useless commodities and the degradation of work itself. The previous neglect of the labor process by Marxists can partly be explained by their confidence that the LTRPF provided sufficient justification for revolutionary politics.

\section{THE DEGRADATION OF LABOR AND THE SCIENCE OF THE SECOND COMING OF COMMUNISM}

Fundamentalist Marxists are sensitive about the caricature of Marx's conception of "the proletariat as a secular equivalent of Hegel's Absolute Spirit, the protagonist of an eschatological philosophy of history whose culmination is the revolution" (Callinicos, 1989, p. 184). But both Braverman's deskilling thesis and the orthodox Marxist theory of crisis derived from the LTRPF provide succor for the fatalism of many fundamentalist Marxists (Hodgson, 1975), the self-appointed guardians of revolutionary intransigence. Their purist abstention from everyday politics is justified by the unstated formula: "the worse it gets, the better that will be" (Gramsci, 1973, p. 161). The Marxist theory of crisis and the deskilling thesis are particularly susceptible to Foucault's (1989) deconstruction of Marxism as eschatological positivism, or as we have put it more prosaically, the science of the second coming of communism. Both the LTRPF and the deskilling thesis purport to provide empirical demonstrations of the necessity and inevitability of revolution. Thus Braverman's "gravedigger thesis once promised an answer to how labor would be conditioned: the vision was that a more homogenised, massified and objectively interdependent working class would be produced out of the capitalist labor process" (Nichols, 1992, p. 16; Tanner, et al., 1992, p. 448).

Labor process theorists have increasingly purged themselves of Braverman's eschatology, of any faith in the second coming, in favor of "a 'materialist' perspective [which] seeks to link theory with empirical investigations of the actual or real developments within contextualized labor processes" (Thompson \& Smith, 2001, p. 61). The subtle suppression of Braverman's messianic Marxist message in labor process theory is an understandable reaction to the ongoing defeat of the Left. It was also advisable for academics to distance themselves from the millenarian Marxist sects, whose abstentionism increasingly took the form of a "Left essentialist position 
[which] denies the desirability or possibility of progressive reforms within capitalist production" (Thompson, 1990, p. 120), or considers any action by workers as "functional to capital unless it leads to revolution" (Tanner, et al., 1992, p. 444). As it got worse for the Left, only the most sectarian purists could persuade themselves that it was actually getting better. But aside from the jargon of Marxist authenticity, we see little connection between the "materialist" version of labor process theory and the historical visions of Marx or Braverman, or for that matter of Foucault or critical theorists (Best, 1995).

As Fundamentalist revolutionary Marxists have acknowledged: "If one were to name that aspect of Marx's thought which is currently regarded with most scepticism even by those generally sympathetic to his ideas, it would probably be [his] belief that the struggle of the working class within capitalism will generate a collective actor capable of installing socialism" (Callinicos, 1989, p. 187). Such loss of faith is evident in the declaration of a leading materialist labor process theorist that

there is a direct and empirically unsustainable link in Marxism between the analysis of the capitalist labor process and a theory of social transformation through class struggle. While a politics of production can be derived from the dynamics of the labor process, this has no automatic progression to a wider social transformation in the Marxist sense. (Thompson, 1990, p. 102; 1989, p. 246)

The "long-running debate concerning the neglect of the 'subjective factor' by Braverman" (Thompson, 1990, p. 114) can be construed as a manifestation of the turn from chiliastic confidence to materialist sociology. The criticism repeatedly leveled at Braverman is that, by deliberately avoiding any discussion of the subjective ideologies of workers, he overlooked the way in which management has to adapt control strategies in order to take account of workers' subjectivity and resistance. But as far as many revolutionary Marxists are concerned, Braverman's position is acceptable, since resistance is only significant to the extent that it prepares workers for greater things. In the words of Rosa Luxemburg, activity "creates the subjective factor of the socialist transformation, for the task of realising socialism," even though it cannot "realise objectively the desired social change" (1989, p. 49).

Revolutionary Marxists maintain that although "change may arise as an unintended consequence of molecular acts of resistance", the importance of resistance is that it can "generate collective agents capable of pursuing the conscious goal of social change" (Callinicos, 1989, p. 11). Furthermore, they maintain that self-limiting resistance, orchestrated from above and aimed solely at effecting reform, is less likely to be successful in achieving even minor reforms than resistance that aims to effect a revolutionary transformation of society. 
In spite of the confidence of Marxist fundamentalists who have incorporated Braverman into their canon of sacred texts, even convinced Marxists have declared labor process theory to be politically uninteresting. They argue that it does not engage with the issues of political and trade union organization, which influence the consciousness and unity of workers, such as the level of confidence among shop-floor activists and the nature of the trade union bureaucracy (Kelly, 1988). The more general point is that:

Class unity in politics does not follow from common embedding of classes in relations of production. It follows instead from political processes proper. Class unity in concrete class relations in factories derives from class unity in politics, not the reverse. (Stinchcombe, 1983, p. 245)

In other words, a shared experience of deskilling in the labor process is neither necessary nor sufficient for workers to engage in unified political activity. Although the immediate interests of workers in production may diverge, their grievances and interests "can be unified into a common political program," but that "unification is a political achievement" (Stinchcombe, 1983, p. 246). Marxist critics allege that labor process theory has been unable to "provide the basis of a theoretically informed praxis" by identifying those tendencies which might lead to "the formation of a collective identity among workers" (Wardell, 1990, pp. 172, 165). But this need not mean the abandonment of historical vision altogether.

Braverman's neglect of the subjective factor is a manifestation of the productivism in Marxist theory, which entails workerism in politics. Workers are privileged in fulfilling the Marxist revolutionary mission on account of their objective location in production rather than any subjective orientation they may display. But at least some indication of a favorable subjective orientation on the part of workers helps to justify revolutionary confidence that the working class is about to become a class for itself and humanity. The Marxist tendency to arbitrarily privilege "production over other forms of actions and interaction" (Best, 1995, p. 72) has been criticized by a long line of radical intellectuals, from critical theorists of the Frankfurt School, such as Adorno and Marcuse, through to various postmodern theorists such as Foucault. Faced with a choice between millenarian or materialist versions of Marxism, it is hardly surprising that disillusioned labor process theorists have increasingly turned to Foucault or critical theory for inspiration.

The fundamentalist Marxist view is that the basis for any form of class compromise will inevitably be undermined because "the economic situation under capitalism is liable to deteriorate independently of the improvements which workers or capitalists consciously seek" (Callinicos, 1989, p. 203). Fundamentalists therefore maintain that compromise should be avoided even when it might appear to be feasible because it would disarm the working class, 
should a crisis subsequently prove unavoidable. The argument is not so much that revolution, however unpleasant, is necessary because economic crises are inevitable, but that since it is impossible to be certain that crises can be avoided indefinitely, it is better not to take the chance of pursuing compromise. In this argument, crises and deskilling can be used interchangeably. Here the influence of Foucault and post-structuralism in labor process theory has reinforced the suspicion towards Marxist metaphysics, which conceives of revolution as the end of history and power relations, and which can be used to rationalize the endurance of inhumanity and suffering in the present.

Critical theorists argue that the Marxist "work model of activity" and "the politics of class" result in "a denial of human plurality". By plurality they:

do not simply mean that we are distinct bodies in space and time, but that our embodied identity and the narrative history that constitutes our selves, gives us a unique perspective on the world. Commonality and community arise and develop among us not only because we are thrust into similar life conditions, but because we create a common perspective together, and build a space of appearance from which to view the world. (Benhabib, 1986, p. 140)

Both Foucauldians and critical theorists have embraced the new social movements that have emerged since '68 and which reflect better the increasingly diverse and complex bases of collective identity than the work model of political activity. But the displacement of Marxist labor process theory by postmodernism and critical theory makes the location of critical management studies in organization studies and business schools problematic. For while Braverman was decidedly anti-management, labor process theory is locked into a discourse concerning management discretion and the subjectivity of labor that may at least concern managers. The detachment of labor process theory from political economy, which we have highlighted here and in previous work (Rowlinson, 1997; Rowlinson \& Hassard, 2001), is exacerbated by the turn to critical theory, which has long been criticized for its neglect of economics (Bottomore, 1984, p. 81). But more importantly, if work is no longer privileged as the source of identity, there is little reason to believe that workers, or managers for that matter, will participate in radical social movements mainly on the basis of their location in production.

\section{DECONSTRUCTING THE NARRATIVE OF CRITICAL MANAGEMENT STUDIES}

Contrary to the pretensions of critical management studies we maintain that its presence as a version of organization studies in business schools is not the culmination of progressive intellectual revelation. Instead, we see the 
anomalous institutional location of critical management studies as the outcome of contingency and the defeat of the Left. As members of the critical management studies community ourselves we recognize that our location presents problems for those of us who aspire to re-elaborate some viable basis for leftist politics.

We are doubtful about the prospects of being able to reiterate an agreed "core" for the continuation of labor process theory in the face of its depoliticization. We are especially doubtful when the advocates of doing so include those we have described as materialist Marxists (Thompson, 1989; 1990; Thompson \& Smith, 2001) as well as more fundamentalist Marxists (Armstrong, 1988; Cohen, 1987; Spencer, 2000). Besides, we are resistant to any attempt to delineate a boundary for labor process theory in order insulate it from critiques inspired by Foucault, post-modernism, or critical theory. Advocates of "core" labor process theory may be able to convince themselves that its dilution is due to the interventions from Foucauldians, postmodernists and critical theorists rather than the defeat of the Left itself, but we are not so convinced. Fortunately, as far as we are concerned, labor process theory has remained contestable. This is because Braverman's prophecy of the inexorable degradation of labor, which provides rhetorical support for revolutionary politics, never became a shibboleth for the revolutionary Left, unlike the prophecy of impending economic crisis, derived from the law of the tendency of the rate of profit to fall (LTRPF), which has become frozen as a catechism for revolutionaries.

The trajectory of labor process theory since Braverman has to be seen in a historical and political context. Braverman believed in the continuing revolutionary potential of the working class. The subsequent defeats suffered by organized workers have sapped the confidence of most labor process theorists in the prospects of workers leading a revolutionary transformation of society. Labor process theorists tend to argue that the deskilling thesis has been refuted as a result of their own sophisticated theorizing and careful observations of changes in the labor process (see Tanner, et al., 1992). But it seems just as likely that political pessimism has been the cause rather than the effect of the deskilling thesis being discarded. While Braverman's deskilling thesis might have been testable as the basis for revolutionary politics during the period of growing working class militancy in the late 1960s and early 1970s, it has become less tenable to advocate such a role for it with the successive defeats of the working class since the mid 1970s.

As a result of the defeat of the Left, erstwhile radical sociologists like ourselves have been compelled to find employment in business schools. In common with Bourdieu (1998, p. 58), our dream, as social scientists, is that part of our research might be useful for the "social movement" against neoliberalism and the conservative revolution. But even more so than other 
intellectuals of the Left who have migrated into institutions of higher education as a consequence of the changing occupational structure and stunting of counter-cultures (Anderson, 2000, p. 23), those of us in business schools have to contend with increasing demands to subordinate truth to usefulness. It is sad, but hardly surprising, that Foucault's critique of "universal intellectuals" has been invoked to condemn as elitist the few leftist academics who are reluctant to abandon their remaining principles in favor of performativity for management practitioners (Jones, 2000).

Foucault is obviously a complex and multifaceted theorist. As White has observed:

If we were to follow what Foucault claims to be his own critical principles, we should not be able to refer to the whole body of texts, the oeuvre, to any presiding authorial intention, to any originating event in the life of the author, or to the historical context in which the discourse arises. (1987, p. 108)

Nevertheless, we feel that the welcome for Foucault in organization studies exemplifies the general reception for postmodernism from erstwhile radicals that gained momentum during the 1980s. Much to the chagrin of Marxist fundamentalists this reception

represented a depoliticization of radical theory, and its aestheticization, so that the critique of bourgeois society was transformed into striking a knowing, ironic attitude towards both the defenders of the status quo and those still benighted enough to wish to overthrow it. (Callinicos, 1995, p. 180)

By invoking Foucault, adherents of critical management studies with teaching positions in business schools can reassure management practitioners that they are not "soft on Marxism" (Jacques, 1996, p. xi). From such quarters, we are treated to lectures on the need to accept that capitalism will be with us for eternity since it is impossible for them to imagine any likely future outside of capitalist relationships (Jacques, 2000, p. 235). For us this stance

betrays the nonoppositional nature of the contemporary "critical" attitude that no longer challenges the basic imperatives of a system bent on global destruction of all life forms; it therefore forsakes a ruthless critique of the grow-or-die logic of the capitalist economy. Lacking such a systematic critique it unavoidably lapses into a Panglossian apology that admits capitalism is, after all, the best of all possible worlds and the end of history. (Best, 1995, p. 129)

We can only glean an impression of the atmosphere facing our "tempered radical" (Meyerson \& Scully, 1995) colleagues in American management and organization studies. We note, for example, the prevalence among those who refer to themselves as "critical" of "one of the commonest forms of 
postmodernist dogma", namely the "intuitive appeal to 'experience', which is absolute because it cannot be gainsaid" (Eagleton, 1996, p. 67). As advanced by the advocates of diversity this may appear to be radical, as it compels would-be "critical" white male American management academics to be somewhat apologetic for their race and sex (Jacques, 1997). But then we find that those self-same academics make no bones about claiming authority from their previous experience as practicing managers or their educational background, having studied for an MBA and a doctorate (Jacques, 1996, p. x; 1999). The implication is that if the study of women in organizations must be left to women, and the study of blacks must be left to blacks, then the study of management must require management experience in order to be able to identify with management practitioners.

It strikes us that if some claim of legitimacy from prior managerial experience is a prerequisite for American management academics being allowed to indulge in critical management studies, anyone like ourselves is unlikely to get much of a hearing. We cannot even compensate for our lack of management experience on the basis of our gender, ethnicity, or sexuality. Like other members of "the white male Western left", the most that can be said for us "is that at least we are not dead" (Eagleton, 1996, p. 25).

We have attempted to provide a historical commentary on the movement of leftist labor process theory into critical management studies. In doing so, we are well aware of the problems with writing such history (e.g., Alvesson \& Deetz, 1999, p. 187). We recognize that we have made many omissions, such as the endless debates over structuralism in Western Marxism. Nevertheless, we reiterate our view that critical management studies is very much a manifestation of the defeat of the Left, a defeat which has undermined more overtly leftist labor process theory. For the time being we must, in common with other members of large organizations who wish to resist a dominant discourse, try to steer a path between tempering our radicalism so much that it becomes risible and committing transgressions that might undermine toleration of our very presence. We suspect that our best hope of survival for the moment is that having suppressed all antagonistic class voices the hegemonic discourse requires a dialogue with the discourse it has suppressed in order to demonstrate its hegemony. The continuing desire to bury Marx is evidence that there is still life in his views, after all no one strives to bury Hegel or Voltaire, since it is clear that their ideas belong to the past (Kagarlitsky, 1999, p. 63).

In writing this paper, we have tried to confront some of the dilemmas facing critical management studies. At least one of the dilemmas is that critical management studies hardly ever seems to address the question posed by, say, Erich Fromm, of what we propose to do today (1997, p. 59). All too often, the answer from critical management studies is to write another paper. But writing 
another paper, which will only be read by other academics, in order to advance our academic careers, can hardly count as "free conscious activity" in any Marxist sense, any more than being compelled to address the problems of management practitioners can be.

\section{REFERENCES}

Ali, T., \& Watkins, S. (1998). 1968: Marching in the Streets. London: Bloomsbury.

Alvesson, M., \& Deetz, S. (1999). Critical theory and postmodernism: Approaches to organizational studies. In S. R. Clegg \& C. Hardy (Eds.), Studying organization: Theory and method. London: Sage.

Alvesson, M., \& Willmott, H. (1992). On the idea of emancipation in management and organization studies. Academy of Management Review, 17, 432-464.

Alvesson, M., \& Willmott, H. (1996). Making sense of management: A critical introduction. London: Sage.

Anderson, P. (2000, January/February). Renewals. New Left Review, 1, 5-24.

Armstrong, P. (1988). Labour and monopoly capital. In R. Hyman \& W. Streeck (Eds.), New technology and industrial relations, (pp. 143-159). Oxford: Blackwell.

Baran, P. A., \& Sweezy, P. M. (1968). Monopoly capital: An essay on the American economic and social order. Harmondsworth: Penguin.

Benhabib, S. (1986). Critique, norm, and utopia: A study of the foundations of critical theory. New York: Columbia University Press.

Berle, A. A., \& Means, G. C. (1932). The modern corporation and private property. New York: Macmillan.

Best, S. (1995). The politics of historical vision: Marx, Foucault, Habermas. London: The Guildford Press.

Bottomore, T. (1984). The Frankfurt school. London: Tavistock.

Bourdieu, P. (1998). Acts of resistance: Against the new myths of our time. Cambridge: Polity.

Braverman, H. (1974). Labor and monopoly capital: The degradation of work in the twentieth century. London; Monthly Review Press.

Braverman, H. (1976). Two comments. Monthly Review 28, 119-124.

Burnham, J. (1962/1941). The managerial revolution. Harmondsworth: Penguin.

Callinicos, A. (1989). Making history. Cambridge: Polity Press.

Callinicos, A. (1995). Theories and narratives: Reflections on the philosophy of history. Cambridge: Polity Press.

Child, J. (1984). Organization: A guide to problems and practice. London: Harper \& Row.

Clark, P. (2000). Organisations in action: Competition between contexts. London: Routledge. 
Clawson, D. (1980). Bureaucracy and the labor process: The transformation of U.S. industry, 1860-1920. London: Monthly Review Press.

Cliff, T. (1979, Autumn). The balance of class forces in recent years. International Socialism, 6, 1-50.

Coase, R. (1990). The firm, the market and the law. London: University of Chicago Press.

Cohen, S. (1987, September-October). A labour process to nowhere? New Left Review, $165,34-50$.

Deal, T., \& Kennedy, A. (2000). The new corporate cultures. London: Textere.

Desai, M. (1979). Marxian economic theory. Oxford: Blackwell.

Eagleton, T. (1996). The illusions of postmodernism. Oxford: Blackwell.

Elbaum, B., Lazonick, W., Wilkinson, F., \& Zeitlin, J. (1979). Symposium: The labour process, market structure and Marxist theory. Cambridge Journal of Economics, 3, 227-30.

Elger, T. (1982). Braverman, capital accumulation and deskilling. In S. Wood (Ed.), The degradation of work?: Skill, deskilling and the labour process. London: Hutchinson, pp. 23-53.

Foster, J. (1989). Conflict at work. Social History, 14, 233-241.

Foucault, M. (1989). The order of things: An archaeology of the human sciences. London: Routledge.

Friedman, A. L. (1977). Industry and labour: Class struggle at work and monopoly capitalism. London: Macmillan.

Friedman, A. L. (1984). Management strategies, market conditions and the labour process. In F. H. Stephen (Ed.), Firms, organization and labour: Approaches to the economics of work organization, (pp. 176-200). London: Macmillan.

Friedman, A. L. (1990). Strawmania and beyond: The development of labour process analysis and critique. Paper given to the Aston/UMIST Organisation and Control of the Labour Process Conference, Manchester.

Fromm, E. (1997). On being human. New York: Continuum.

Galbraith, J. K. (1967). The new industrial state. Boston: Houghton Mifflin.

Galbraith, J. K. (1993). The culture of contentment. London: Penguin.

Gramsci, A. (1973). Selections for prison notebooks. London: Lawrence \& Wishart.

Habermas, J. (2001). The postnational constellation: Political essays. Cambridge: Polity.

Harman, C. (1984). Explaining the crisis: A Marxist reappraisal. London: Bookmarks.

Harman, C. (1998). The fire last time. London: Bookmarks.

Hodgson, G. (1975). Trotsky and fatalistic Marxism. Nottingham: Spokesman.

Jacques, R. (1996). Manufacturing the employee: Management knowledge from the 19th to 21st centuries. London: Sage. 
Jacques, R. (1997). The unbearable whiteness of being: Reflections of a pale, stale male. In P. Prasad, A. J. Mills, M. Elmes, \& A. Prasad (Eds.)., Managing the organizational melting pot: Dilemmas of workplace diversity, (pp. 80-106). London: Sage.

Jacques, R. (1999). Developing a tactical approach to engaging with "strategic" HRM. Organization 6, 199-222.

Jacques, R. (2000). Roy Jacques writes back. In C. Pritchard, R. Hull, M. Chumer, \& H. Willmott (Eds.), Managing knowledge: Critical investigations of work and learning, ( pp. 235-236 ). London: Macmillan.

Jameson, F. (1984). Postmodernism, or cultural logic of late capitalism. New Left Review 146, 53-93.

Jones, D. (2000). Knowledge workers " $r$ " us: Academics, practitioners, and "specific intellectuals". In C. Pritchard, R. Hull, M. Chumer, \& H. Willmott (Eds.), Managing knowledge: Critical investigations of work and learning, (pp. 158-175). London: Macmillan.

Kagarlitsky, B. (1999). New realism, new barbarism: Socialist theory in the era of globalization. London: Pluto.

Kelly, J. (1988). Trade unions and socialist politics. London: Verso.

Klein, N. (2001). No logo. London: Flamingo.

Knights, D. (1990). Subjectivity, power and the labour process. In D. Knights \& H. Willmott (Eds.), Labour process theory, (pp. 297-335). London: Macmillan.

Knights, D., \& Wilmott, H. (Eds.). (1990). Labour process theory. London: Macmillan.

Lazonick, W. (1979). Industrial relations and technical change: The case of the selfacting mule. Cambridge Journal of Economics 3, 231-262.

Littler, C. R. (1990). The labour process debate: A theoretical review, 1974-1988. In D. Knights \& H. Willmott (Eds.), Labour process theory, (pp. 46-94). London: Macmillan.

Littler, C. R., \& Salaman, G. (1982). Bravermania and beyond: Recent theories of the labour process. Sociology, 16, 251-269.

Luxemburg, R. (1989). Reform or revolution. London: Bookmarks.

Mandel, E. (1981). Introduction. In K. Marx (Ed.). Capital volume three, (pp. 9-90). Penguin, Harmondsworth: Penguin.

Marcuse, H. (1964). One dimensional man. Boston: Beacon Press.

Marglin, S., \& Schor, J. (Eds.). (1990). The golden age of capitalism. Oxford: Oxford University Press.

Meyerson, D. E., \& Scully, M. A. (1995). Tempered radicalism and the politics of ambivalence and change. Organization Science 6, 585-600.

Neimark, M., \& Tinker, T. (1987). Identity and non-identity thinking: A dialectical critique of the transaction cost theory of the modern corporation. Journal of Management 13, 661-73. 
Nelson, D. (1980). Frederick Taylor and the rise of scientific management. Madison, WI: University of Wisconsin Press.

Nichols, T. (1970). Ownership control and ideology. London: George Allen \& Unwin.

Nichols, T. (1992). The labour process before and after the labour process. Presented to the 10th International Labour Process Conference, Aston University, Birmingham, AL.

Perrow, C. (1986). Complex organizations: A critical essay (3rd edition). New York: McGraw Hill.

Peters, T. J., \& Waterman, R. H. (1982). In search of excellence. New York: Harper \& Row.

Pitelis, C. (1987). Corporate capital: Control, ownership, saving and crisis. Cambridge: Cambridge University Press.

Pfeffer, J. (1998). The human equation: Building profits by putting people first. Harvard, MA: Harvard Business School.

Pritchard, C. (2000). Know, learn and share!: The knowledge phenomena and the construction of a consumptive-communicative body. In C. Pritchard, R. Hull, M. Chumer, \& H. Willmott (Eds.), Managing knowledge: Critical investigations of work and learning, (pp. 176-198). London: Macmillan.

Rowlinson, M. (1987). Organisations and institutions: Perspectives in economics and sociology. London: Macmillan.

Rowlinson, M., \& Hassard, J. (2001). Marxist political economy, revolutionary politics, and labor process theory. International Studies of Management \& Organization 30, 85-111.

Sawyer, M. (1979). Theories of the firm. London: Weidenfield \& Nicolson.

Scott, J. (1997). Corporate business and capitalist classes. Oxford: Oxford University Press.

Semmler, W. (1982). Theories of competition and monopoly. Capital and Class, 18, 91-116.

Shaikh, A. (1991). Falling rate of profit. In T. Bottomore (Ed.), A dictionary of Marxist thought (2nd edition), (pp. 185-186). Oxford: Blackwell.

Spencer, D. (2000). Braverman and the contribution of labour process analysis to the critique of capitalist production-twenty-five years on. Work, Employment \& Society 14, 223-244.

Stinchcombe, A. (1983). Economic sociology. London: Academic Press.

Tanner, J., Scott, D., \& O’Grady, B. (1992). Immanence changes everything: A critical comment on the labour process and class consciousness. Sociology, 26, 439-454.

Thompson, P. (1989). The nature of work: An introduction to debates on the labour process. London: Macmillan.

Thompson, P. (1990). Crawling from the wreckage: The labour process and the politics of production. In D. Knights \& H. Willmott (Eds.), Labour process theory, (pp. 95-124). London: Macmillan. 
Thompson, P., \& Smith, C. (2001). Follow the redbrick road: Reflections on pathways in and out of the labor process debate. International Studies in Management \& Organization 30, 40-67.

Thurrow, L. (1996). Almost everywhere: Surging inequality and falling real wages. In C. Kaysen (Ed.), The American corporation today. Oxford: Oxford University.

Wardell, M. (1990). Labour and labour process. In D. Knights \& H. Willmott (Eds.), Labour process theory, (pp. 153-176). London: Macmillan.

Weick, K. (1979). The social psychology of organizing (2nd edition), Reading MA: Addison-Wesley.

Wheen, F. (1999). Karl Marx. London: Fourth Estate.

White, H. (1987). The content of the form: Narrative discourse and historical representation. London: John Hopkins University Press.

Williamson, O. E. (1980). The organization of work: A comparative institutional assessment. Journal of Economic Behavior and Organization, 1, 5-38.

Willmott, H. (1990). Subjectivity and the dialectics of praxis: Opening up the core of labour process analysis. In D. Knights \& H. Willmott (Eds.), Labour process theory, (pp. 336-378). London: Macmillan.

Zeitlin, M. (1989). The large corporation and contemporary classes. Cambridge: Polity Press.

${ }^{\mathrm{i}}$ Names in alphabetical order.

John Hassard is Professor of Organizational Analysis at the University of Manchester Institute of Science and Technology and Senior Research Associate at the Judge Institute of Management Studies, Cambridge University. He taught previously at the London Business School and the universities of Cardiff and Keele. He has published ten books including Time, Work and Organization (1989), Sociology and Organization Theory (Cambridge 1993), Postmodernism and Organizations (Sage 1994), Organization/Representation (1999) and Body and Organization (2000). His research interests lie in organization theory and empirical studies of enterprise reform, with special reference to transitional economies.

John Hogan is a Doctoral Student in the School of Management, Royal Holloway, University of London. His doctoral research concerns the implications of Information Communication Technology for the politics and processes of trade unionism.

Michael Rowlinson is Professor of Organization Studies in the Business School, University of North London, 277-281 Holloway Road, London, N7 8HN, UK. Email m.rowlinson@unl.ac.uk Tel +44020 7753 3313. Address for correspondence on the paper. His last book, Organisations and Institutions: Perspectives in Economics and Sociology (1997), deals with the relationship between organizational economics, especially transaction cost economics, and organization theory, focusing on the relative importance of power and efficiency in explanations for the rise of the modern corporation, the separation of ownership from control, and divisions of labor and hierarchy. 
Copyright $\odot 2003$ EBSCO Publishing 